\title{
ВMJ Global Health Explaining the outcomes of the 'Clean India' campaign: institutional behaviour and sanitation transformation in India
}

\author{
Val Curtis
}

To cite: Curtis V. Explaining the outcomes of the 'Clean India' campaign: institutional behaviour and sanitation transformation in India. BMJ Global Health 2019;4:e001892. doi:10.1136/ bmjgh-2019-001892

Handling editor Stephanie M Topp

Received 6 August 2019 Revised 29 August 2019 Accepted 11 September 2019

A Check for updates

(c) Author(s) (or their employer(s)) 2019. Re-use permitted under CC BY-NC. No commercial re-use. See rights and permissions. Published by BMJ.

DCD, London School of Hygiene and Tropical Medicine, London, UK

Correspondence to Professor Val Curtis; val.curtis@Ishtm.ac.uk

\section{ABSTRACT}

Introduction Many less developed countries are struggling to provide universal access to safe sanitation, but in the past 5 years India has almost reached its target of eliminating open defaecation.

Objective To understand how the Indian government effected this sanitation transformation.

Methods The study employed interviews with 17 actors in the government's 'Clean India' programme across the national capital and four states, which were analysed using a theory of change grounded in Behaviour Centred Design. Results The Swachh Bharat Mission (Gramin) claims to have improved the coverage of toilets in rural India from $39 \%$ to over $95 \%$ of households between 2014 and mid2019. From interviews with relevant actors we constructed a theory of change for the programme, in which highlevel political support and disruptive leadership changed environments in districts, which led to psychological changes in district officials. This, in turn, led to changed behaviour for sanitation programming. The prime minister set an ambitious goal of eliminating open defaecation by the 150th birthday of Mahatma Gandhi (October 2019). This galvanised government bureaucracy, while early success in 100 flagship districts reduced the scepticism of government employees, a cadre of 500 young professionals placed in districts imparted new ideas and energy, social and mass media were used to inform and motivate the public, and new norms of ethical behaviour were demonstrated by leaders. As a result, district officials became emotionally involved in the programme and felt pride at their achievement in ridding villages of open defaecation.

Conclusions Though many challenges remain, governments seeking to achieve the sustainable development goal of universal access to safe sanitation can emulate the success of India's Swachh Bharat Mission.

In a country as powerful as India-dreaming of space conquest, building roads, development-the fact that the priority of the entire Indian administration is to end open defaecation is extraordinary. (Interview No 14)

\section{INTRODUCTION}

In 2007 readers of the $B M J$ chose the introduction of clean water and sewage disposal- the sanitary revolution'-as the most important

\section{Key questions}

What is already known?

- At least 47 countries are not on track to reach the sustainable development goal of universal access to safe sanitation by 2030 and some 0.6 billion people are still defecating in the open.

- It is not clear how governments in low-income countries can be galvanised to act to resolve this pressing public health problem.

What are the new findings?

- The experience of the Clean India programme suggests that countries can almost eliminate open defaecation.

- The success of the programme was due to the following factors: setting of ambitious targets; use of modern communications strategies and monitoring technology; and provision of visible reward and recognition for employees.

\section{What do the new findings imply?}

- Disruptive leadership is needed to create working environments where, sometimes jaded, civil servants are given an opportunity to make a difference.

Politicians who embrace the cause of sanitation may find that there are votes in toilets.

medical milestone since $1840 .{ }^{1}$ Yet safe sanitation, essential for the prevention of infectious disease, for child growth, for gender equity and for human dignity, ${ }^{2-10}$ has yet to reach a quarter of the world's inhabitants. ${ }^{11}$

Most countries of South East Asia and sub-Saharan Africa have struggled to improve their rates of toilet ownership. One country, however, has bucked this trend. Rural India, once responsible for $60 \%$ of the world's open defaecators, ${ }^{12}$ has over the past five years been transformed by a government-led programme named the Clean India Mission (Swachh Bharat Mission (Gramin) or SBM(G)). In 2014, fewer than four in 10 rural Indian households owned a toilet; by the middle of 2019 , official figures put coverage at over $95 \% .{ }^{13}$ While it is hard to be certain of the actual numbers of 
toilets in such a vast and diverse country, it is clear that a major national transformation has taken place. This is an unlikely success story, both because Indian bureaucracy is not famous for its ability to create rapid change, and because ending open defaecation is a surprising target for a political campaign.

In this paper I aim to explain how this sanitation transformation happened. From interviews with national, state and district actors, I deduce a theory of change for the behaviour of government officials in districts and use this to draw lessons for other nations wishing to emulate the success of the Clean India campaign.

\section{METHODS}

\section{Study sample}

I interviewed 17 people chosen to represent a range of types of $\operatorname{SBM}(G)$ actors operating at national, state and district levels. Participants came from the capital and four states, with varied performance on toilet coverage. Of the interviewees, six were career civil servants, five were assigned to work in $\operatorname{SBM}(G)$, four were employed by partner organisations outside of government and two were academics. Of the total, four worked in national government, four at state level and six at district level. The aim was to have approximately four people in each type of position (some interviewees represented several types) and to continue interviewing until saturation was reached. ${ }^{14}$ Fifteen of the 17 interviewees were Indian nationals and seven were female. Eleven interviews took place face-to-face and six over Skype; each lasted for 60-80 min. Interviews took place between May and July 2018. All of the people approached agreed to take part, although one delegated the interview to a colleague. I also drew on my experience as an occasional adviser on behaviour change to the Indian Ministry of Drinking Water and Sanitation (MDWS).

\section{Study ethics}

Interviewees were supplied with an information sheet about the study, were informed that their participation would be anonymous and were asked to sign a consent form. Identifying information was removed before transcription of interviews. Ethical approval was granted by the London School of Hygiene \& Tropical Medicine (no
15261) and permission to conduct the study was granted by the MDWS.

\section{Patient and public involvement}

No patients or members of the public were involved in the design, analysis or reporting of this study.

\section{Data collection and analysis}

The interviews followed a structured format that included a request to describe the SBM programme, questions about administrative structures, decision-making systems, programme financing, technical issues and specific challenges. I also asked participants about their own circumstances and their motives for working in $\operatorname{SBM}(G)$. I followed COREQ guidelines for the design, analysis and reporting of qualitative research. ${ }^{15}$

Interviews were conducted in English and recorded. Following transcription, I employed the steps of framework analysis-namely, (i) familiarisation, (ii) identifying a thematic framework, (iii) indexing, (iv) charting and (v) mapping and interpretation. ${ }^{16}$ I employed the framework of Behaviour Centred Design $(\mathrm{BCD})^{17}$ to index and chart the data using NVivo version $11 .^{18}$ Figure 1 shows the generic BCD theory of change framework, depicting how interventions perturb the physical, biological and social environment of actors. These changes affect their psychology (at an executive, motivated or habitual level), and lead to changes in their behaviour. These behavioural changes, when compounded, lead to changes in the state of the world-for example, better toilet provision in India. All these changes take place in a particular geographical, political, economic and cultural context.

\section{RESULTS}

Figure 2 shows the theory of change for $\operatorname{SMB}(G)$ constructed from an analysis of the interviews using the BCD framework. On the right are the observed changes to the state of the world (improved toilet coverage and use). Left of this, in grey, is the change in behaviour of district officials. In blue, are the psychological changes in these actors, brought about by changes in their operating environments, shown in green. The orange boxes are aspects of the intervention (ie, the activities of $\mathrm{SBM}(\mathrm{G})$
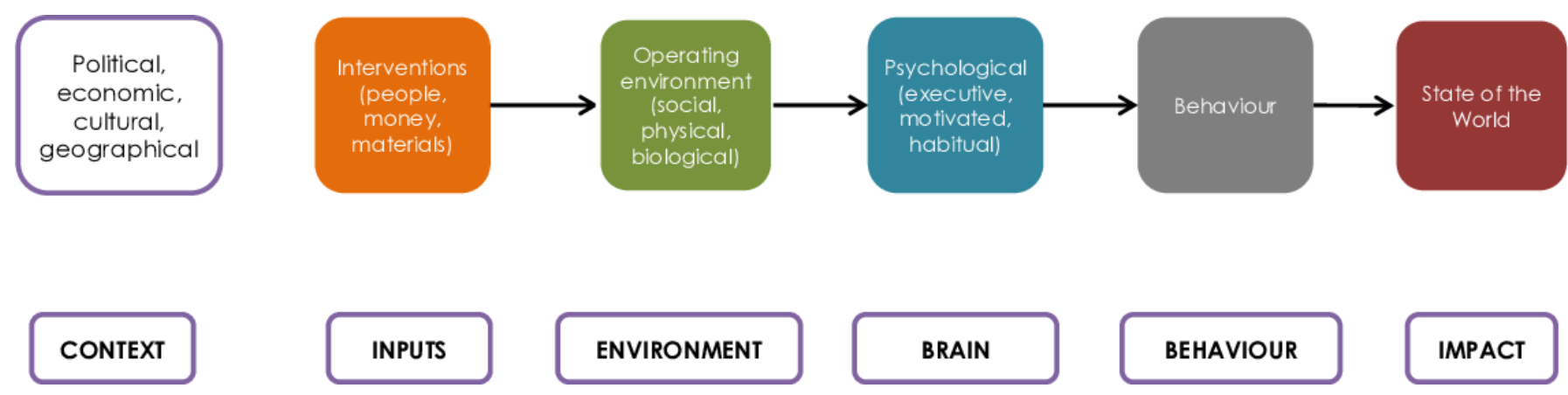

IMPACT

Figure 1 Generic Behaviour Centred Design theory of change. 


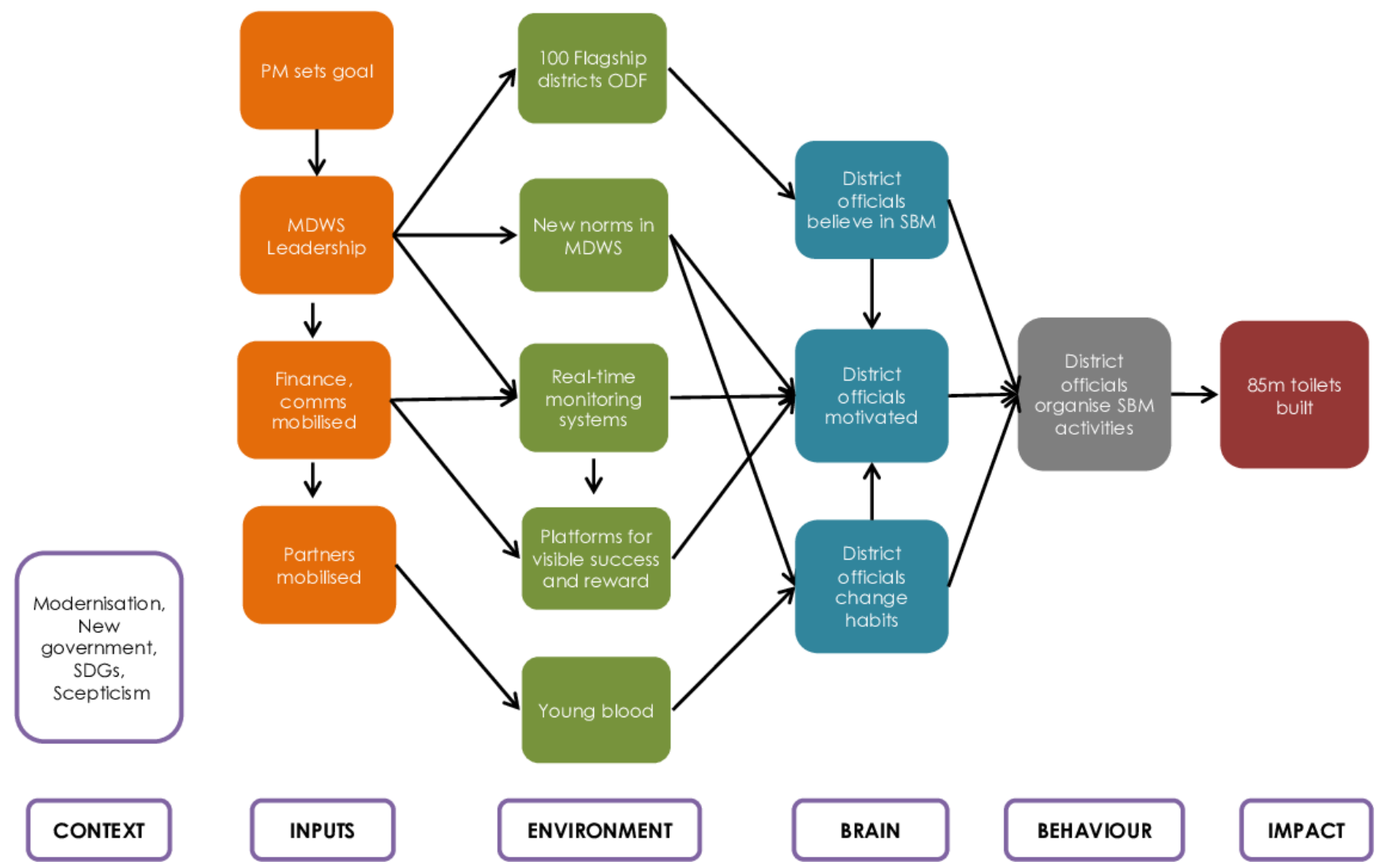

Figure 2 Theory of change for the Swachh Bharat Mission (Gramin). MDWS, Ministry of Drinking Water and Sanitation; ODF, open defaecation free; SBM, Swachh Bharat Mission; SDGs, sustainable development goals.

as led by the MDWS that caused this cascade of changes. Below I detail these changes, working from inputs to impact.

\section{Interventions (inputs to SBM(G))}

All interviewees ascribed the initial impetus for the Swachh Bharat Mission to the prime minister, Narendra Modi. In 2014, in his inaugural speech from the ramparts of the Red Fort in Delhi, Modi announced his plan for India to become free from open defection in 5 years, by 2 October 2019, in honour of the 150th anniversary of the birth of Mahatma Gandhi. The setting of this 'big hairy audacious goal ${ }^{19}$ made the need for radical changes in the government's normal approach evident:

[We are in] mission mode delivery arrangement, where you have a sunset clause that you have to achieve in a given time period......So, it's a very different working paradigm. (01)

[In normal practice] the government might have said that we have 10 years to make India open defaecation free. So we might have done squat for 7 years and started working in the eighth year and then asked for a 5 year no-cost extension. (16)

Officials at all levels referred to the prime minister's evident commitment to SBM:

The major change is that the political leadership came from the prime minister's office... ...to reach all the communities, civil societies, religious leaders, famous people of India, actors or people in sport. Involving everybody at the same time for a national cause under the lead of the PM. (14)

...the fact that this is led by the prime minister - it is high on the agenda of every district collector. It has led to government functionaries being on their toes all the time and also reaching out to the people in a way that has never happened before. (12)

And the PM kept up pressure over the life of the programme:

So, it was not just a political announcement, but they backed it with serious attention over last 4 years, I think that's quite dramatic. That's one big game changer. (16)

...the PM referred to Swachh Bharat in 35 of his 50 addresses to the nation on All India Radio between October 2014 and December 2018. (10)

Breaking with administrative norms to appoint staff on the basis of seniority, the prime minister sought out a technocrat to lead $\operatorname{SBM}(G)$ within the MDWS. The chosen secretary was a sanitation specialist and was also unusual in having worked both within the Indian administrative service, and outside of it in international bodies. This gave him the ability to navigate the government hierarchy, but also to see where it might be disrupted. 
In terms of technical leadership, this time the people put in place to lead this campaign are people with global experience that have worked abroad. They are aware of what is happening in the world in terms of sanitation programming, successes and failures, so there is great openness to learning in this programme. (14)

The ministry team led a consultation exercise with states to gather lessons from a succession of previous sanitation campaigns, and to work out what it would cost to achieve the goal of an open defaecation free (ODF) India. The total bill was estimated at some US $\$ 20$ billion over 5 years, or about US $\$ 4.00$ per head of the population per year. ${ }^{20}$ In addition, the team negotiated a loan of US $\$ 1.5$ billion from the World Bank. ${ }^{21}$ The ministry also asked the World Bank, UNICEF, WaterAid and other support agencies to augment their technical assistance to states, and asked philanthropic foundations (Tata Trusts and the Bill and Melinda Gates Foundation) to fund the recruitment of consultants to a project management cell:

The consultants have given a new dimension to the working of the ministry. Previously we were working like a government setup, but with the coming of this young blood...

...they have given momentum to the programme. (02)

Unusually for India, the management cell was integrated within the ministry rather than sitting outside of it. The $\operatorname{SBM}(G)$ team thus had access to government communications channels and to the cabinet and prime minister:

What Modi has done is picked up these bureaucrats and said you have direct access to me... (09)

A further input that distinguished $\operatorname{SBM}(G)$ from standard Indian government programmes was a new strategy for communications. The team recognised early on that it was important to constantly communicate; downwards through the government hierarchy to programme actors, outwards to the population as a whole and to partners in the private and development sectors, and also, critically, back upwards to SBM's political masters. Key influencers had to be kept on board:

We started delivering and then we started communicating that to the people who matter - like media, like the political masters, they need to feel that the thing is moving. Then there are academics, the international community, the sort of people who are influencers, who can spread the word. It's like chicken and egg: when you start doing well, then nothing succeeds like success, but it needs to be communicated... (11)

So point is, if you want political leadership and you get it, then you have to nurture it... (14)

Mass media played a major role in keeping all these audiences supportive and involved:

...all of our communication has become much more world class. Indian government ads are [normally] easily identifiable from their look and feel - they are dull, boring and preachy and nobody wants to watch them. But in this ministry the ads are very exciting and entertaining... (10)
Honestly I don't know if promoting stuff on social media is leading to behaviour change in rural India, but it does make urban India more aware about what happening in rural areas, for that is also important. (12)

\section{Changes to the environment in districts}

The theory of change depicts how these inputs (disruptive leadership, mobilisation of human and financial resources, new modes of communication) changed the operating environment for staff working in India's more than 600 districts. The new leadership team in the ministry recognised that the first barrier to overcome was widespread staff scepticism, engendered by the experience of having seen many previous campaigns falter. ${ }^{22}$ They needed to make district officials believe that change was possible. One hundred districts were therefore targeted for an 'early-win' campaign. Their heads, the district collectors, were invited to national workshops, and were offered resources and, unusually, direct access to the leadership, to enable them to resolve any problems they encountered. By the end of 2016, most of these flagship districts had declared that they were ODF. This model was then duplicated across the country.

That is one of the great achievements (of SBM), they really have made sure that there is great support for any collector who wants to achieve this. (17)

The new leaders of SBM disrupted social norms in districts by modelling behaviour that was results-oriented and ethical. One interviewee recounted:

If the secretary is going to the field [normally], the collector's job is to be the protocol officer, to receive him at the airport, ensure his dietary requirements, see his arrangements are proper. Your job is to carry his briefcase. But this secretary focuses on the task in hand, he asks the collector important questions, rather than where to buy this handloom saree for his wife... This changes the professional ethics. Then the administrators know that this guy will ask for results rather than where to go shopping. (09)

Several interviewees told of the surprise that they felt when they saw a photograph of a top ministry official climbing into a toilet pit to empty it in the national newspapers. $^{23}$ One top state official dug toilet pits herself. Another related her initiation to the SBM programme by a trainer which violated the norm :

'Tatti' [shit] is the most disgusting and vile word in Hindi. And he was just like: 'tatti tatti'... .... and I could not stop giggling. It is not even a word you may use, you may use this word at home, but not if there is a guest or someone. (10)

Many interviewees felt that such activities had caused a change of norms in society, and by extension, in districts:

So this is quite unique... ...5 or 6 years back you could not even talk about defaecation. And now you see that the whole of India is expert on the issue of open defaecation. (14)

A further change to the operating environment of districts was the use of technology to monitor and 
encourage progress. Collectors were set targets by the leadership in Delhi and then, unusually, were held to account. They were expected to report on progress in face-to-face meetings, in regular multi-participant video conferences and online.

Video and satellite conferences were my two important communication tools to connect with people and officials from across all the districts. I used video conferences to get figures on how many toilets had been built and to hand out targets. (15)

District collectors were trained on, and encouraged to sign up for, social media, and to use email:

[It is] rare for a bureaucrat to reply within an hour to an email. That means he has got email on his phone. Babus [bosses] still don't do it to this day. (10)

In addition, the MDWS created a live 'dashboard'; a website displaying progress on sanitation coverage showing the number of toilets built and the percentage of households covered. ${ }^{24}$ In many states this system worked automatically via a mobile phone app that was updated by village authorities in real time, as toilets were built and funds disbursed to householders' electronic bank accounts.

These improvements in communications technology provided an environment in which districts knew they could be held publicly to account, but also gave them an opportunity to show off their success. Rather than being forgotten in remote corners of the country, those collectors and their staff who did well were held up as examples on social media, invited to receive awards at multiple ceremonies involving local, state or national dignitaries and some were given awards by the prime minister himself.

The secretary... ...travels a lot to see what's happening on the ground and he tweets almost every day about the good things that are happening. So, this provides a lot of motivation to the system. (08)

We had this workshop to felicitate the spouses which really touched all of them. Many of these wives... ...said that nobody has ever acknowledged the work that we do. (15)

A further means by which 'business-as-usual' in districts was disrupted was the introduction of 'fresh young blood'. Aside from deploying technical consultants, development partners were asked to recruit a cadre of new, young and enthusiastic fellows. Five hundred preraks were hired and assigned to support districts, where they took on a variety of roles.

This is how the programme works: they take fellows from districts which have become ODF and put them in districts or states wherever it's required according to the skills and the needs... (08)

The preraks are an astonishing innovation... They have been terrific... (17)

Preraks described how they offered flexible support to districts, filling in where needed:
I had a collector who would call me pretty much on a daily basis. If I didn't meet him, he would text me and ask about the update. Eventually, I would run a lot of workshops and he even sent me to different locations because [he said] 'I can't understand what the problem is there, why don't you go and check out what the problem is and just address it...' (07)

Preraks supported each other and shared solutions to problems, often using social media:

But in terms of everyday things that we needed to carry out, we were calling each other on WhatsApp or email... 'I heard that you guys have a lot of dysfunctional toilets, how are you working on this?' ...that was on a WhatsApp group. (08)

\section{Psychological changes}

In figure 2 innovations that changed the social and technological environments in districts led to psychological changes (belief, motivation and habitual response) of the relevant officials. First, staff had to believe that change was possible. Officials repeatedly described how they had joined a civil service out of a desire to 'serve', but had been frustrated by bureaucracy and stasis:

It's just pushing up against the wall which is not going to move ever. So, why am wasting the good years of my youth and all my energy and ideas on this? (10)

But as they saw progress, staff begun to believe that the sanitation situation could be changed:

Because it gives you so much conviction, you know, what the world thought is impossible is being done in my time. (01)

As the results of their work became more visible, district officials related their pride at their achievements:

So now when I travel with my family they say: 'see what is happening to your Swachh Bharat...'...I am 'Swachh Bharat Champ' they call me. (03)

Staff described their motivation for working in SBM using emotive terms:

There is a lot of passion for the first time in my sanitation business for many years. This is the first time that I have seen such a powerful country being mobilised in such a genuine and realistic way. (14)

...it is glamorous $(07)$

...disgust with the kind of situation people have lived in in our villages for such a long time... (06)

I think this whole country has been amazingly galvanised [by this] compelling creation, amazing euphoria..., ...the sanitation programme is a very adventurous, courageous and romantic venture. (01)

However, the motive that was most often mentioned by staff working in districts was the opportunity that working in the SBM had given them to 'make a difference': 
It gives you satisfaction when you see that we are heading a programme that is being implemented and that is being successful and people are owning it. (03)

Because here I think I can give my best output and can contribute in assisting my bosses so that they can do it well too. $(02)$

The new technological environment also changed the habitual responses of officials-for example, by making it easy for them to monitor progress closely:

So now when you are in a village you log into the app [and] all the Swachh Bharat mission toilets are mapped there with the beneficiary name, with the photographs, everything is there. (06)

Further, the new norms of behaviour set by national officials led to new working habits such as abandoning air-conditioned offices and spending more time in the field.

\section{Changes in behaviour in districts}

The cascade of changes in the operating environment and in the psychology of actors in SBM led to new behaviour in districts-the level at which staff have the mandate, operational staff and budgetary autonomy to organise development activities. Interviewees reported that the most important determinant of progress in latrine construction was the level of involvement of the district collector (DC). A DC who had taken on the challenge of SBM would typically move into 'campaign mode', making building toilets her/his priority, sometimes neglecting other activities to do so. The work comprised reviewing the sanitation status of blocks (administrative units) and villages, setting targets for toilet construction, organising payments to self-help groups and contractors, training masons and huge numbers of social mobilisers (swachhagrahis), organising mobilisation events, monitoring results and verifying the ODF status of villages.

DCs used a range of strategies to galvanise these activities: setting targets for blocks and villages to become ODF, arranging disbursement of funds, having weekly problem-solving meetings with block staff and sometimes, following up progress daily using social media.

The commitment of some of these collectors is quite extraordinary. Some use WhatsApp to call people at 4 in the morning to make sure they are up for the nigrani samiti [morning visit to open defaecation grounds]. Quite amazing! (17)

So they [block coordinators] feel happy and motivated as there is regular follow-up. And as I call them almost every day, so they also hold meetings almost every 2 to 3 days. (03)

Perhaps the biggest change in the behaviour of district level staff was the move from 'business-as-usual' to a personal engagement with the cause:

If you are not out in the field, you are not present and people don't see you, then people will not get excited. (11)
Everybody was more excited about the mission, because the collector himself was sitting with us. (08)

So you try to inspire people, motivate people, appeal to them, persuade them to do it fast, quickly and so on, in the mode of pulse polio [national eradication campaign], where in matter of a week or 10 days you can simultaneously start the work of construction and of triggering people. (15)

\section{Change in the state of the world (impact)}

What, finally, was the overall impact of these changes in the administrative system under the $\operatorname{SBM}(G)$ ? The government of India has made repeated efforts to improve the sanitation conditions of its rural population; figure 3 shows the results. After the national census of 1981 put national sanitation coverage at only $1 \%$, the Central Rural Sanitation Program was launched in 1986. This increased coverage to $9 \%$ and evolved into the Total Sanitation Campaign, which began in 1991. In the following 20 years, coverage improved by some $1 \%$ a year, reaching $31 \%$ by $2011 .{ }^{25}$ Despite a relaunch of the campaign, as the Nirmal Bharat Abhiyan, India failed to meet its millennium development goal to halve the rate of those with no access to sanitation by $2015 .{ }^{26}$

By contrast, 4 years after the 2014 launch of Swachh Bharat, official figures suggested that over 80 million toilets had been built; 500 districts and almost half a million villages had been declared free of open defaecation. ${ }^{27}$ Figure 3 suggests that the rate of toilet building in rural areas was around 10 times that of previous campaigns. In tandem with accelerating increases in sanitation coverage, government figures suggest that open defaecation has also decreased, dropping by $3 \%$ a year between 2000 and 2014 and by $12 \%$ a year from 2015 to 2019. ${ }^{11}$

A number of unpublished surveys suggest that the government monitoring system overestimates the true levels of toilet coverage. ${ }^{28}{ }^{29}$ Interviewees gave reasons for discrepancies between individual surveys and government figures that included inaccuracies in the original government baseline against which progress is reported, the omission from the SBM programme of households with old toilets which had fallen out of use, and systemic incentives to over-report results. Nevertheless, interviewees described exceptional progress in improving toilet coverage over the past 4 years, transforming India from a country where the majority defaecated in the open, to one where the majority of people have, and use, toilets.

I don't think there is any historic parallel of any country anywhere in the world, shifting numbers on such a scale. That will change the global indicators. I think that the story is not whether it is $85 \%$, right, or $90 \%$, right, the story is the fact that there is a tremendous shift. (16)

While interviewees were positive about the gains made by the SBM, there were also worries about the sustainability of these gains over the long term: 


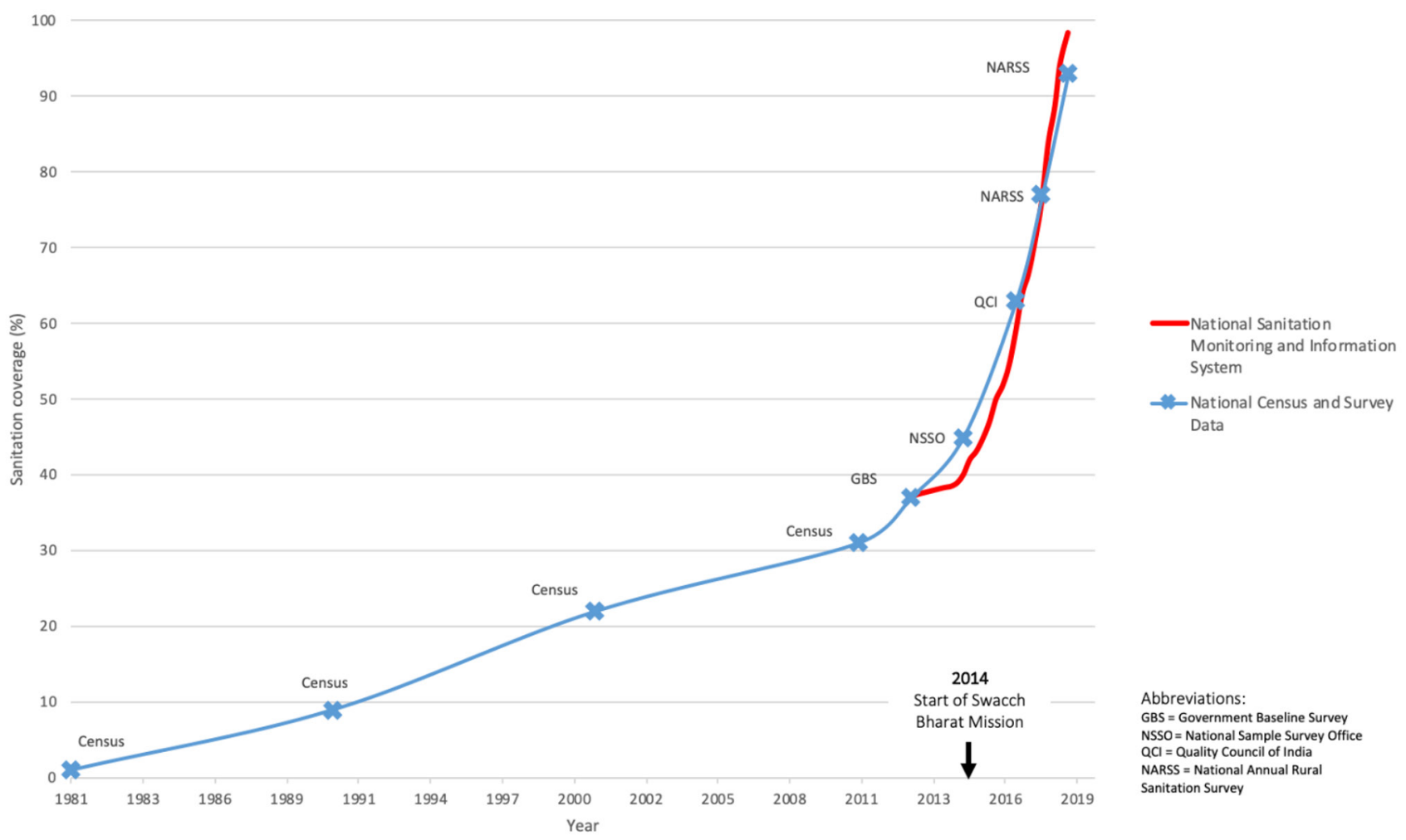

Figure 3 Household toilet coverage in India 1981-2018 according to surveys and the national monitoring system.

we brought India from A to B which is an outstanding achievement but there is recognition that behaviour change is complex, there is unfinished business and there is necessity to invest beyond the campaign so that we have a real impact by the end of the SDG era. (14)

As the final deadline for SBM looms, political attention to the unfinished last mile on sanitation will inevitably shift to other pressing social problems, such as rural water supply. In the face of this the MDWS is trying to embed sanitation in national policy, and plans to continue to make funds available to complete and sustain the gains of SBM.

On sustainability, of course the ministry is also aware; they have started focusing on something called ODF Plus, which looks at the sustainability issue. (13)

\section{Context}

Drawing transferable lessons from a programme's theory of change requires understanding its particular context. ${ }^{30}$ The $\operatorname{SBM}(\mathrm{G})$ programme took advantage of opportunities presented by the prevailing national political situation, of improvements in living conditions in rural India and of the proliferation of communications technology. It also drew on the experience of previous sanitation programmes, and on the global push to meet the sustainable development goals. Contextual factors that hindered progress, on the other hand, included a general scepticism of government-sponsored programmes, political division, where some states were not supporters of the current government, and the many other competing demands for social investment in India.

Interviewees pointed out how the political context was key in the launch of SBM, where a swing towards a nationalist and pro-Hindu party provided an opportunity to capitalise on the symbolism of purity, cleanliness of the mother country and the example of Gandhi. This was expected to translate into electoral support:

Sanitation is something each family needs every day. And through his programme, Modi is able to reach out to almost all the households in the country. And a toilet becomes synonymous with Modi. So, Modi is equal to Swachh Bharat and Swachh Bharat is equal to a toilet. So, this has given him immense visibility, immense publicity and immense connection with crores of households in India. (01)

Indeed, observers have suggested that the prime minister's evident commitment to rural sanitation was a factor in the success of the ruling party at the 2019 general elections. $^{31} 32$

You see, good sanitation is good politics. (01)

The new SBM goals were set for a nation in the midst of modernisation, where millions have emerged from poverty, and most people have improved their housing and gained access to electricity, water, mass communications and education. ${ }^{33}$ India was therefore ready for 
modern toilets, and had the communications networks necessary to spread the idea rapidly.

The $\operatorname{SBM}(G)$ programme did not emerge anew but was set up in the context of a long line of previous national sanitation campaigns. These had had limited success, but provided experience concerning what worked and what did not.

The Swachh Bharat Mission is preceded by several other missions; the Total Sanitation Mission, Nirmal Bharat Abhiyan and other campaigns. When the Swachh Bharat mission started we were very much aware of this. We can't say that those programme were a total failure, these contributed to building momentum and creating awareness, and some of these toilets are still in use. ...definitely they left imprints. (05)

Both the national and international situation was favourable to SBM. International agreement to meet the sustainable development goals reminded Indian leaders that, though their country had made progress in many ways, sanitation conditions still lagged far behind those of countries with comparable levels of development.

\section{DISCUSSION}

\section{Principal findings}

While it will still take some time to completely realise the ambition for an ODF India, the country has made large strides in this direction over the past 5 years. In rural areas of other low-income countries, around 1.5 billion people still lack access to basic sanitation services, and 0.6 billion defaecate in the open. ${ }^{34}$ This study offers insights and lessons for the governments of countries that are looking to improve the sanitation conditions of their populations:

1. There are votes in toilets. The Indian experience suggests that political commitment at the head of government can galvanise an administration to a goal as unlikely as ending open defaecation, and that this may be rewarded politically.

2. Disrupt institutional norms. From the outset, the leaders of $\operatorname{SBM}(G)$ set out to disrupt the bureaucratic norms of government. The leadership modelled ethical norms of commitment to progress, new enthusiastic young staff in districts helped to create norms of adaptive learning, enthusiasm and personal engagement and the norm of polite silence about matters faecal was repeatedly and deliberately violated.

3. Believe the impossible. A key driver of the success programme was the 'big hairy audacious goal' to make India 'open defaecation free' by 2 October 2019. Standard development programmes tend to be conservative, setting less risky, but more plausible, goals (for example, the Tanzanian government has set a target of $85 \%$ coverage with improved toilets by 2030 ). However, such targets neither provide a compelling vision nor a sense of urgency. SBM shows other countries that ambitious plans for sanitation transformation can galvanise behaviour change in institutions.
4. Set targets and monitor them. Many development programmes set targets, but few follow them up as relentlessly as did the Swach Bharat team. Making use of electronic data gathering and real-time, public dashboards, the ministry team reviewed progress district by district, every month, sought to resolve any bottlenecks and held district collectors to account for their results.

5. Reward and recognition. Once districts began to meet their targets, their progress was deliberately and publicly celebrated. Officials from successful districts were lauded and presented with awards at national, state and local events, and they, in turn, gave awards to leaders and mobilisers in successful villages. Successful officials were praised in tweets and Instagram posts. As a result, officials were full of pride at their achievements and were motivated to make efforts that went well beyond their normal pattern of work.

6. Constant $360^{\circ}$ communications. Unusually for a government programme, the $\operatorname{SBM}(G)$ embraced modern communication strategies and media technologies. The centre kept relevant stakeholders, such as MPs, journalists, academics, development partners and private sector players, informed and involved, using social media, mass media, high-profile events, conferences, teleconferences and personal visits. District officials learnt to use communications technologies such as email and social media to follow progress, to short-circuit sometimes cumbersome official channels and to encourage one another.

7. Focus on behaviour and sustainability. Learning from previous programmes in India an elsewhere, the SBM made major efforts to support behaviour change through mass training programmes and local innovation.

8. A passion for sanitation. A surprising finding from this research was the degree of emotion shown by the respondents when they described their engagement with the SBM programme. Motives driving their participation included justice, creativity, nurture, status and disgust. ${ }^{35}$ From top to bottom of the hierarchy, almost every interviewee described the programme in emotive terms; whether as adventurous, glamorous, exciting, fulfilling, pride-generating, satisfying, or humbling. According to one interviewee:

I will be living testimony to the fact that India will become ODF and I will be making a huge difference in lives of millions of people, because I am associated. The difference that we will make in rural India, the profound impact it will have on the lives of poor people is very, very satisfying, inspiring, humbling. (01)

Much has been written about sanitation programming, such as the choice of technology ${ }^{36}$ motives for the adoption of toilets, ${ }^{37} 38$ provision of subsidy, ${ }^{39}{ }^{40}$ community participation, ${ }^{41} 42$ environmental factors ${ }^{43}$ and health outcomes of sanitation programmes, ${ }^{44-46}$ but only a few published studies have tried to unpick the successes and failures of government-led programmes. 
A 2012 study of the of the previous Total Sanitation Campaign in India ${ }^{22}$ blamed its poor results on a lack of political priority and leadership, a lack of confidence in the possibility of success, the misuse of subsidies, poor monitoring systems and a top-down supply-led approach. The results of the current study suggests that the leaders of $\operatorname{SBM}(G)$ had learnt how to resolve, at least some, of these problems, by capitalising on political support, broadcasting the successes of the programme, using electronic banking to pay subsidies directly to households, employing technological platforms for monitoring and by emphasising behaviour change. The use of electronic technology to monitor progress is not new to India; it has been employed successfully in sanitation programmes in Indonesia ${ }^{47}$ and Zambia. ${ }^{48} \mathrm{~A}$ lack of political will has long been lamented in the field of sanitation (for example, in India, ${ }^{43}$ Nepal, ${ }^{49}$ Tanzania $^{50}$ and Ghana ${ }^{51}$ ), but the SBM example suggests a reason why politicians should become involved-there are votes in toilets!

The factors responsible for the success of SBM, to some extent, echo those identified as important for success in large-scale health programmes more generally. One survey of 20 proven programmes concluded that political will, technological innovation, expert consensus about the approach, effective use of information by management, and sufficient financial resources were critical ${ }^{52}$ It also pointed to the importance of government ownership of development programmes, if success is to be sustained.

The setting by the government of ambitious, "not-quite achievable', big hairy audacious goals was undoubtedly one of the factors in the success of the SBM. Nevertheless, the pursuit of success can have what Rajkotia describes as an ugly side: "the high stakes, the ambition and the expectation can instil a fear of failure, stifle risk-taking and innovation, and lead to the fabrication of achievement. ${ }^{~} 53$ However, for SBM a high level of awareness of previous failures led to innovation-for example, an attempt to focus on behaviour change and on construction targets. The strategy has also undoubtedly led to inflated claims about SBM's results. But, as Rajkotia also points out, aspirational targets are important because they can rally governments and civil society to focus their energies on social development. He suggests that it might thus be unfair to chastise them for failure to achieve their aspirations completely. Countries should recognise that there is a virtuous circle by which aspirational targets can drive success, both through success itself, and by the learning that accrues from acknowledging, accepting and understanding failure to achieve them, partially or completely. ${ }^{54}$

Even when toilets have been built, and counted, people might still not use them. A study in Orissa suggested that while the sanitation campaigns of 1999-2012 increased latrine coverage substantially, over one-third of people with toilets were still not using them. ${ }^{55}$ Obtaining good data on use is difficult, but there are indications that the longer people have toilets the more likely they are to use them. ${ }^{56}$ Evidence suggests that of all the structural, cultural, psychological and material factors determining toilet acquisition and use, the most important seems to be the perceived social norm of not defaecating in the open. ${ }^{38}$ Given the much wider presence of toilets and greater discussion of their use, it may be that toilet use has reached a tipping point, beyond which their use will only increase.

A novel aspect of this study was the attention paid to the settings and motives of civil servants. This study documented positive emotions associated with participation in $\operatorname{SBM}(G)$. In Bangladesh, Hanchett found that a factor in the success of the national sanitation programme was the enthusiasm and pride of union council chairmen and their shared experience. ${ }^{57}$

\section{Strengths and weaknesses of the study}

Courtesy bias may be partially responsible for the almost unanimously positive response of interviewees about their experience of SBM, but the enthusiasm of the SBM participants was clearly genuine. Given the huge size and heterogeneity of India, a larger study with a broader range of interviewees from a broader range of states might have provided further lessons. However, data saturation was acheived early, with few new insights emerging after about 12 interviews. ${ }^{14}$

This study was unusual in that it focused on the behaviour of district officials within government institutions, rather than on the effect of sanitation programming on villages and households. A more complete investigation might have analysed the factors leading to behaviour change at every level in the hierarchy, from leaders, through ministry, state, district, block and village, through to householders. A future analysis of the factors leading to behaviour change in households could be expected to provide further important information.

The study also focused purely on sanitation programming aimed at households in rural India. How to achieve universal access to sanitation in urban settings in low-income countries remains a large and largely unsolved problem.

It might be asked how far is India a special case, and can the achievements of the SBM be transferred to other countries? India is one country among many in which modernisation is proceeding rapidly. Tusting et al show that housing is improving across sub-Saharan Africa, ${ }^{58}$ and our research in Tanzania suggests that toilet promotion can be linked to this process of modernisation. ${ }^{59}$ India is also one of many countries in the global south with political leaders with ambitions for transformation, as was demonstrated when 53 government delegations attended a summit on SBM held in Delhi in October 2018. India differs from many countries with incomplete sanitation in its low level of reliance on external monetary help. Yet the, seemingly huge, amount it made available for toilet building amounted to only around US $\$ 4$ per person per year, a sum that could be recouped in financial savings associated with lower healthcare and other costs. ${ }^{60}$ Case studies suggest that poverty is rarely 
a barrier to the achievement of public health goals. ${ }^{52}$ Hence it seems likely that other countries can - if they wish - emulate India's sanitation success.

The theory of change perspective of Behaviour Centred Design was applied for the first time to behaviour change in institutions. It provided a new, relatively straightforward method to understand the behaviour of actors in government. A new aspect of the approach was its ability to investigate the role of psychological factors such as motives, and the social and physical factors in the operational environment of the key actors. It allowed the creation of a structured and plausible theory of change from which it was possible to derive lessons that should be of use to other institutions wanting to improve the quality of public services.

\section{Future research}

SBM measured its success against a baseline set in 2013, but interviewees pointed out that many families had been left out of SBM. The government will need to tackle the tough 'last mile' problem of remote and left-out rural households, and find better sanitation solutions for the urban poor, before it can fully claim to have met its objective to declare the country free from open defaecation. Questions remain about the sustainability of the achievements of SBM. Much could be learnt by studying the different experience and differing levels of success across India's widely varied 600+ districts. Future studies, including the national census of 2021, will disclose the long-term trajectory of the gains claimed by SBM.

Finally, it is increasingly understood that people working in institutions are motivated to act by a range of factors beyond immediate financial advantage. ${ }^{61} 62$ As one interviewee said:

All of us who are members of civil services, we joined the service with the vision for the betterment of society. (05)

A closer investigation of the motives of civil servants in national action programmes, such as the successful Swach Bharat programme in India, might provide important lessons about how best to stimulate and reward such activity. This could have consequences for better public services beyond the urgent struggle to get the sanitary revolution to everyone on the planet.

Acknowledgements I wish to thank Robert Aunger, Sarah Bick, Kavita Chauhan, lan Ross, Astrid Thorseth and the interviewees.

Funding This study was funded by London School of Hygiene \& Tropical Medicine. Competing interests None declared.

Patient consent for publication Not required.

Provenance and peer review Not commissioned; externally peer reviewed.

Data availability statement Data may be obtained from a third party and are not publicly available.

Open access This is an open access article distributed in accordance with the Creative Commons Attribution Non Commercial (CC BY-NC 4.0) license, which permits others to distribute, remix, adapt, build upon this work non-commercially, and license their derivative works on different terms, provided the original work is properly cited, appropriate credit is given, any changes made indicated, and the use is non-commercial. See: http://creativecommons.org/licenses/by-nc/4.0/.

\section{ORCID iD}

Val Curtis http://orcid.org/0000-0001-8994-2878

\section{REFERENCES}

1. Ferriman A. BMJ readers choose the "sanitary revolution" as greatest medical advance since 1840. BMJ 2007;334:111.2-111.

2. Wolfe M, Kaur M, Yates T, et al. A systematic review and metaanalysis of the association between water, sanitation, and hygiene exposures and cholera in case-control studies. Am J Trop Med Hyg 2018;99:534-45.

3. Pickering AJ, Djebbari $\mathrm{H}$, Lopez $\mathrm{C}$, et al. Effect of a communityled sanitation intervention on child diarrhoea and child growth in rural Mali: a cluster-randomised controlled trial. Lancet Glob Health 2015;3:e701-11.

4. Hammer J, Spears D. Village sanitation and child health: effects and external validity in a randomized field experiment in rural India. $J$ Health Econ 2016;48:135-48.

5. Prüss-Ustün A, Bartram J, Clasen T, et al. Burden of disease from inadequate water, sanitation and hygiene in low- and middle-income settings: a retrospective analysis of data from 145 countries. Trop Med Int Health 2014;19:894-905.

6. Sumpter $\mathrm{C}$, Torondel B. A systematic review of the health and social effects of menstrual hygiene management. PLoS One 2013:8:e62004.

7. Kjellén M, Pensulo C, Nordqvist P, et al. Global review of sanitation systems trends and interactions with menstrual management practices - Report for the menstrual management and sanitation systems project. Stockholm, Sweden: Stockholm Environment Institute (SEI), 2012

8. Sahoo KC, Hulland KRS, Caruso BA, et al. Sanitation-related psychosocial stress: a grounded theory study of women across the life-course in Odisha, India. Soc Sci Med 2015;139:80-9.

9. Routray P, Torondel B, Clasen T, et al. Women's role in sanitation decision making in rural coastal Odisha, India. PLoS One 2017:12:e0178042.

10. UNICEF. Gender-responsive water, sanitation and hygiene: key elements for effective wash programming. UNICEF, 2017.

11. UNICEF/WHO. Progress on household drinking water, sanitation and hygiene 2000-2017. special focus on inequalities. New York: United Nations Children's Fund (UNICEF) and World Health Organization (WHO), 2019.

12. $\mathrm{WHO} /$ Unicef. Progress on sanitation and drinking water - 2015 update and MDG assessment. Geneva: WHO/Unicef, 2015.

13. Government of India. National annual rural sanitation survey (NARSS) 2018-19, 2019. Available: http://www.indiaenvironment portal.org.in/content/461686/national-annual-rural-sanitation-surveynarss-2018-19/ [Accessed 27 Aug 2019].

14. Forum qualitative Sozialforschung/Forum: qualitative social research. Sample size and saturation in PhD studies using qualitative interviews, 2010.

15. Tong A, Sainsbury P, Craig J. Consolidated criteria for reporting qualitative research (COREQ): a 32-item checklist for interviews and focus groups. Int J Qual Health Care 2007;19:349-57.

16. Ritchie J, Spencer L, O'Connor W. Carrying out qualitative analysis. In: Qualitative research practice: a guide for social science students and researchers, 2003: 219-62.

17. Aunger R, Curtis V. Behaviour centred design: towards an applied science of behaviour change. Health Psychol Rev 2016;10:425-46.

18. QIP. NVivo qualitative data analysis software, version 11, 2017.

19. Collins JC, Porras Jl. Built to last: successful habits of visionary companies. Random House, 2005.

20. Mehta M. Public finance at scale for rural sanitation-a case of Swachh Bharat mission, India. Journal of Water, Sanitation and Hygiene for Development 2018;8:359-73.

21. World Bank. World Bank approves US\$1.5 billion to support India's universal sanitation initiatives, 2015. Available: http://www. worldbank.org/en/news/press-release/2015/12/15/world-bankapproves-usd-1point5-billion-support-india-universal-sanitationinitiatives [Accessed 27 Aug 2019].

22. Hueso A, Bell B. An untold story of policy failure: the Total Sanitation Campaign in India. Water Policy 2013;15:1001-17.

23. Times of India. Scooping out stigma: bureaucrat cleans toilet pit in Warangal village, 2017. Available: https://timesofindia.indiatimes. $\mathrm{com} /$ city/hyderabad/scooping-out-stigma-bureaucrat-cleans-toiletpit-in-warangal-village/articleshow/57229583.cms [Accessed 27 Aug 2019].

24. Government of India. Swachh Bharat mission (Gramin), 2019. Available: https://sbm.gov.in/sbmdashboard/ [Accessed 27 Aug 2019]. 
25. Ghosh A, Cairncross S. The uneven progress of sanitation in India. Journal of Water, Sanitation and Hygiene for Development 2014;4:15-22.

26. World Health Organization. Progress on drinking water, sanitation and hygiene: 2017 update and SDG baselines. In: Progress on drinking water, sanitation and hygiene: 2017 update and SDG baselines, 2017.

27. Government of India. Swachh Bharat mission (Gramin), 2018. Available: https://sbm.gov.in/sbmdashboard/ [Accessed 2 Oct 2018].

28. RICE. Changes in open defecation in rural North India: $2014-2018$, 2019. Available: https://riceinstitute.org/research/changes-in-opendefecation-in-rural-north-india-2014-2018-2/ [Accessed 27 Aug 2019].

29. Indian Express. CAG report picks holes in Gujarat's open defecationfree claim, 2018. Available: https://indianexpress.com/article/india/ cag-report-picks-holes-in-gujarats-open-defecation-free-claim5367438/ [Accessed 27 Aug 2019].

30. Bonell C, Fletcher A, Morton M, et al. Realist randomised controlled trials: a new approach to evaluating complex public health interventions. Soc Sci Med 2012;75:2299-306.

31. Indian Express. Lok Sabha election results: NDA schemes resonate in 115 poor districts, bring 60\% seats, 2019. Available: https:// indianexpress.com/elections/lok-sabha-election-results-ndaschemes-resonate-in-115-poor-districts-bring-60-seats-5745609/ [Accessed 27 Aug 2019].

32. Times of India. Future shift: welfare schemes may have worked well for Modi government, it will need something more if re-elected, 2019. Available: https://timesofindia.indiatimes.com/blogs/toieditorials/future-shift-welfare-schemes-may-have-worked-wellfor-modi-government-it-will-need-something-more-if-re-elected/ [Accessed 27 Aug 2019].

33. CIA. The world Factbook: India, 2019. Available: https://www.cia gov/library/publications/the-world-factbook/geos/in.html [Accessed 27 Aug 2019].

34. United Nations Children's Fund (UNICEF) and World Health Organization (WHO). Progress on household drinking water, sanitation and hygiene 2000-2017. special focus on inequalities. New York: United Nations Children's Fund (UNICEF) and World Health Organization (WHO), 2019.

35. Aunger R, Curtis V. The anatomy of motivation: an evolutionaryecological approach. Biol Theory 2013;8:49-63.

36. Chunga RM, Ensink JHJ, Jenkins MW, et al. Adopt or adapt: sanitation technology choices in urbanizing Malawi. PLoS One 2016;11:e0161262.

37. Jenkins MW, Curtis V. Achieving the 'good life': why some people want latrines in rural Benin. Soc Sci Med 2005;61:2446-59.

38. Novotný J, Hasman J, Lepič M. Contextual factors and motivations affecting rural community sanitation in low- and middleincome countries: a systematic review. Int J Hyg Environ Health 2018;221:121-33.

39. Pattanayak SK, Yang J-C, Dickinson KL, et al. Shame or subsidy revisited: social mobilization for sanitation in Orissa, India. Bull World Health Organ 2009;87:580-7.

40. Guiteras R, Levinsohn J, Mobarak AM. Encouraging sanitation investment in the developing world: a cluster-randomized trial. Science 2015;348:903-6.

41. Chambers R, Kar K. Handbook on community-led total sanitation. Brighton: IDS, 2008

42. Venkataramanan V, Crocker J, Karon A, et al. Community-led total sanitation: a mixed-methods systematic review of evidence and its quality. Environ Health Perspect 2018;126:026001.
43. O'Reilly K, Louis E. The toilet TRIPOD: understanding successful sanitation in rural India. Health Place 2014;29:43-51.

44. Clasen T, Boisson S, Routray P, et al. The effect of improved rural sanitation on diarrhoea and helminth infection: design of a clusterrandomized trial in Orissa, India. Emerg Themes Epidemiol 2012;9:7.

45. Humphrey JH, Mbuya MNN, Ntozini R, et al. Independent and combined effects of improved water, sanitation, and hygiene, and improved complementary feeding, on child stunting and anaemia in rural Zimbabwe: a cluster-randomised trial. Lancet Glob Health 2019;7:e132-47.

46. Tofail F, Fernald LC, Das KK, et al. Effect of water quality, sanitation, hand washing, and nutritional interventions on child development in rural Bangladesh (wash benefits Bangladesh): a cluster-randomised controlled trial. Lancet Child Adolesc Health 2018;2:255-68.

47. Mukherjee N. Building environments to support sustainability of improved sanitation behaviours at scale: levers of change in East Asia. In: Sustainable sanitation for all: experiences, challenges, and innovations, 2016: 53.

48. Osbert N, Manchikanti S, Hoehne A, et al. Real time monitoring of rural sanitation at scale in Zambia using mobile-to-web technologies, 2015.

49. McMichael C. Toilet talk: eliminating open defecation and improved sanitation in Nepal. Med Anthropol 2018;37:294-310.

50. Jiménez A, Mtango FF, Cairncross S. What role for local government in sanitation promotion? Lessons from Tanzania. Water Policy 2014;16:1104-20.

51. Mariwah S. Sanitation: the neglected Siamese twin of water in achieving the millennium development goals (MDGs) in Ghana. GeoJournal 2018;83:223-36.

52. Levine R. Case studies in global health: millions saved. Jones \& Bartlett Publishers, 2007.

53. Rajkotia Y. Beware of the success cartel: a plea for rational progress in global health. BMJ Glob Health 2018;3:e001197.

54. Storeng KT, Abimbola S, Balabanova D, et al. Action to protect the independence and integrity of global health research. BMJ Glob Health 2019;4.

55. Barnard S, Routray P, Majorin F, et al. Impact of Indian total sanitation campaign on latrine coverage and use: a cross-sectional study in Orissa three years following programme implementation. PLoS One 2013;8:e71438.

56. Novotný J, Ficek F, Hill JKW, et al. Social determinants of environmental health: a case of sanitation in rural Jharkhand. Sci Total Environ 2018;643:762-74

57. Hanchett S. Sanitation in Bangladesh: revolution, evolution, and new challenges. Sustainable sanitation for all: experiences, challenges, and innovations 2016;31.

58. Tusting LS, Bisanzio D, Alabaster G, et al. Mapping changes in housing in sub-Saharan Africa from 2000 to 2015. Nature 2019:568:391-4.

59. Czerniewska A, Muangi WC, Aunger R, et al. Theory-driven formative research to inform the design of a national sanitation campaign in Tanzania. PLoS One 2019;14:e0221445.

60. Hutton G, Haller L. Evaluation of the costs and benefits of water and sanitation improvements at the global level: water, sanitation, and health, protection of the human environment, World Health Organization, 2004

61. Wilson DS, Hayes SC, Biglan A, et al. Evolving the future: toward a science of intentional change. Behav Brain Sci 2014;37:395-416.

62. Thaler RH, Sunstein CR. Nudge: improving decisions about health, wealth, and happiness. Yale University Press, 2008. 